\title{
OTORITAS HIERARKI KUTUB AL-SITTAH DAN KEMANDEGAN KAJIAN FIKIH
}

\author{
Muhammad Habibi Siregar \\ Fakultas Dakwah dan Komunikasi IAIN Sumatera Utara \\ Jl. Willem Iskandar Pasar V Medan Estate, Medan, 20371 \\ e-mail:mhd_habibi_srg@yahoo.com
}

\begin{abstract}
Abstrak: Tulisan ini mencoba melakukan pemetaan masalah yang membuat kajian fikih stagnan sebagaimana diklaim oleh sebagian ilmuwan hukum Islam. Otoritas hierarki Kutub al-Sittah ternyata merupakan persoalan mendasar yang membatasi ulama berijtihad. Hal ini dikarenakan adanya pembatasan terhadap penggunaan kitab-kitab hadis di level tertinggi. Istilah Kutub al-Sittah semestinya diletakkan sebagai kitab fikih, yang ketika penggunaan awalnya dianggap kitab hadis. Menurut penulis, hal ini membuat Kutub al-Sittah cenderung menolak kritikan, sebab ada dimensi kesakralan di dalamnya. Karenanya perlu dilakukan kontekstualisasi terhadap pemahaman nash hadis yang dianggap untuk mengikuti perubahan sosial. Menurut penulis deduksi terhadap nilai teks nash tidak mengenyampingkan teks nash sebagai pijakan dalam pengembangan konsep maslahat. Otentisitas kajian fikih terkait dengan nilai-nilai normatif nash, namun hal tersebut tidak bisa langsung diterapkan dalam kehidupan.
\end{abstract}

\begin{abstract}
The Authority of Kutub al-Sittah Hierarchy and the Stagnant of Fiqh Studies. This paper tries to map predicaments that contributed to fiqh studies that had been claimed to be stagnant at least by a few Islamic legal scholars. The authority of Kutub al-Sittah hierarchy, in fact, has become an important problem that restricted the learned scientific community or ulama to practice ijtihad. This stemmed from the limitation of the hadits books use at the highest level. The so called Kutub al-Sittah should be properly signified as fiqh book. According to the author, this makes Kutub al-Sittah seems to be resistant to criticism, due to the sacred and intrinsic dimension in it. Therefore, it is urgent that understanding the argument of Traditions which are relevant and in line with the social dynamics should be contextualized. He also maintains that legal deduction of the text of the Traditions does not necessarily overrule the principle values of the text as a foundation for the maslahat concept. In addition, the argues that the authority of the study of Islamic jurisprudence is closely related to the normative values of the text, but nonetheless such norms could not be directly applied to the real life.
\end{abstract}

Kata Kunci: otoritas, Kutub al-Sittah, fikih 


\section{Pendahuluan}

Istilah kutub al-sittah merupakan terminologi yang lazim digunakan dalam menggambarkan kitab-kitab hadis standar yang berlaku di dunia Islam. Otoritas yang terbangun di masyarakat Islam begitu kuat tertanam di dalam sanubari mereka, sehingga istilah ini sudah dianggap sebagai sesuatu yang bersifat qath î. ${ }^{1}$ Penggunaan istilah kutub al-sittah ini memberi justifikasi hukum yang tinggi terhadap suatu masalah. Sedikit sekali penelitian yang ada bisa mengungkap asal mula munculnya istilah ini dalam dunia Islam. Istilah kutub al-sittah yang dikenal selama ini identik dengan kitab-kitab hadis. Pengaburan sejarah telah melanda dunia Islam selama ini tentang istilah kutub al-sittah yang identik dengan kitab-kitab hadis yang bersifat hirarki setelah abad ke-5 $\mathrm{H}$.

Faktanya jauh sebelum ulama hadis menggunakan istilah kutub al-sittah pada abad ke-2 $\mathrm{H}$ istilah ini sudah sangat dikenal di masa dinasti Abbasiah khalifah Harun al-Rasyid ketika qadi al-kubra Hasan al-Shaibani. Istilah kutub al-sittah pada masa qadi Hasan alShaibani merujuk pada enam kitab-kitab fikih yang lazim digunakan oleh mazhab Hanafi. ${ }^{2}$ Keenam kitab rujukan bagi hakim-hakim yang berada di wilayah kekuasaan Dinasti Abbasiah. Keenam kitab fikih yang dikenal dalam mazhab Hanafi dianggap sebagai kitab undangundang negara yang lazim disebut dengan kutub al-sittah. ${ }^{3}$ Kitab-kitab fikih tersebut bersifat equal dalam arti seorang hakim boleh menjadikan salah satu dari ke enam kitab tersebut sebagai rujukan dalam memutus suatu perkara. Hal di atas menggambarkan betapa maju peradaban umat Islam pada masa itu yang memiliki enam kitab perundangundang dasar dalam hukum, bahkan bila dibandingkan dalam masyarakat modern hanya memiliki satu kitab undang-undang dasar. Istiah kutub al-sittah yang awalnya identik dengan kitab undang-undang negara Dinasti Abbasiah memerintah di wilayah sangat luas memberi legacy yang tidak hilang di benak umat Islam. Apresiasi yang tinggi umat Islam terhadap kutub al-sittah memberi gestald tersendiri terhadap istilah ini yang memiliki sejarah gemilang sebagai umat yang memiliki peradaban yang sangat tinggi.

Kontesasi antar ahli ra'yu dan ahli hadis mulai muncul pada masa khalifah alMakmun dari Dinasti Abbasiah ketika dia membuka kran selebar-lebarnya usaha penerjemahan buku-buku asing ke dalam bahasa Arab. Pengaruh pemikiran Hellenisme yang cenderung mengapreasiasi logika Yunani mempengaruhi corak berpikir umat Islam khususnya di kalangan ilmuwan. Masa paling gemilang dari Dinasti Abbasiah terjadi pada masa pemerintahan Harun al-Rasyid yang membuat umat Islam berada pada puncak

${ }^{1}$ M. Glen Coper, "The Qur'an's Self-Image: Writing and Authority in Islamic's Scripture," Journal of the American Oriental Society 123.1 (January-March 2003), h. 247-248.

${ }^{2}$ Enam kitab fikih tersebut terdiri dari; al-Ushl, al-Mabsuth, Jami' al-Shaghir, Jami‘ al-Kâbir, al-Siyâr, al-Ziyâdât.

${ }^{3}$ Paul M Cobb, "Reinterpreting Islamic Historiography: Harun al-Rashid and Narative of the Abbasid Caliph," dalam Journal the American Oriental Society 12.1 (January-March 2001), h. 121. 
keemasan dari segala bidang ilmu pengetahuan. Tidak terkecuali dalam bidang hukum dengan lahirnya kutub al-sittah yang menjadi rujukan hakim-hakim berperkara di pengadilan. Puncak peselisihan ahli ra'yun dengan ahli hadis ketika terjadi peristiwa mihna pada masa khalifah al-Mutawakkil yang menimbulkan efek yang luar biasa terhadap konstelasi berpikir waktu itu. Sejarah membuktikan pasca peristiwa mihna ulama-ulama Muktazilah yang rasional tidak boleh lagi eksis, bahkan karya-karya mereka tidak boleh dipublikasikan kepada khalayak dianggap sesat. ${ }^{4}$

Momentum di atas digunakan pihak ahli hadis untuk mengambil tempat yang ditinggalkan oleh ahli ra'yun untuk melakukan penetrasi pemikiran yang selama ini didominasi oleh corak logic oriented. Ulama-ulama hadis mulai menyusun formulasi dalam membangun corak baru dalam masyarakat Muslim dengan menyusun dan membuat genre baru dalam Islam. Mereka menyusun kitab-kitab hadis yang dianggap sebagai rujukan dalam beristimbat hukum, sehingga tidak mengherankan banyak dari kitab-kitab hadis yang eksis sekarang memiliki pola seperti kitab-kitab fikih. ${ }^{5}$ Hal tersebut dilakukan untuk lebih menunujukkan eksistensi mereka di dalam masyarakat Muslim. Ada beberapa istilah yang digunakan oleh ulama hadis dalam menggambarkan tentang kitab-kitab hadis standar yang dapat dijadikan sebagai rujukan hukum seperti kutub al-khamsah, kutub al-sittah, kutub al-sab'ah, kutub al-thamaniyah, kutub al-Tis'ah. Kenyataanya hanya kutub al-sittah saja yang dikenal dan mendapat respon yang baik dari masyarakat Islam hingga kini. Hal tersebut disebabkan istilah kutub al-sittah ini sudah sangat familiar dengan umat Islam karena sudah dikenal sejak zaman khalifah Harun al-Rasyid menjadikan sebagai kitab perundang-undangan negara. Kemudian ulama hadis menggunakan istilah kutub al-sittah kembali sebagai cara instan untuk mendapatkan pengakuan dari umat Islam. Kutub al-sittah yang sebelumnya identik dengan kitab-kitab fikih berubah menjadi kitabkitab hadis. Hal tersebut memiliki dampak yang luar biasa terjadi pada masa-masa berikutnya sehingga menimbulkan persepsi yang kekultusan yang melekat dengan kutub al-sittah. Bila kutub al-sittah dianggap sebagai kitab fikih yang memiliki nuansa profan berubah menjadi sakral dengan bentuk hierarki bukan horizontal. Kutub al-sittah pada masa Hasan al-Shaibânî adalah kitab-kitab fikih bersifat equal artinya tidak dalam bentuk hierarki sehingga memberi kebebasan kepada hakim dalam menggunakan kitab-kitab tersebut. ${ }^{6}$ Berbeda halnya ketika istilah kutub al-sittah ini digunakan oleh ulama hadis dengan menggunakan metode hirarki di dalamnya. Artinya kitab Shahîh al-Bukhârî dan Shahîh Muslim dianggap sebagai kitab hadis rujukan utama dalam berhujjah dengan alasan

${ }^{4}$ Madelung, Wilferd, Sabine Schmidtke, Rational Theology in Interfaith Communication: Abu l-Husayn al-Basri's Mu'tazili Theology among the Karaites in Fatima Age (Leiden: Brill, 2006), h. 144.

${ }^{5}$ Christopher Melchert, "Early Renunciants as Hadith Transmitters," dalam The Muslim World 92.33:4 (Fall 2002), h. 407-418.

${ }^{6}$ Benjamin Jokisch, Islamic Imperial Law: Harun al-Rashid's Codification Project (Berlin: Walter De Gruyter, 2007), h. 234-240. 
tingkat kesahihan keduanya dianggap sebagai yang paling tinggi. ${ }^{7}$ Masalahnya timbul ketika konsep hierarki yang ditekankan oleh ulama hadis menjadi kontra produktif dengan

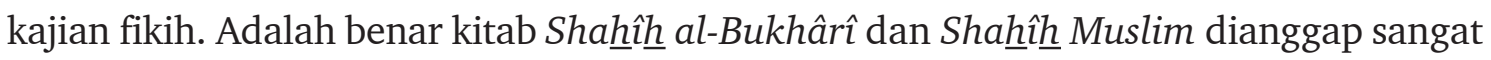
fasih berbicara masalah-masalah yang menyangkut dengan ibadah mahdhah seperti Salat, zakat, dan haji. Akan tetapi, hampir tidak ada dijumpai hadis-hadis yang menyangkut dengan masalah suksesi kepemimpinan di sana atau hal-hal yang bersifat non-ibadah ritual.

Sejarah membuktikan pasca berakhirnya kodifikasi hadis pada akhir abad ke- $4 \mathrm{H}$ tidak ada lagi lahir ulama fikih sekaliber dengan empat imam-imam mazhab; Imam Abu

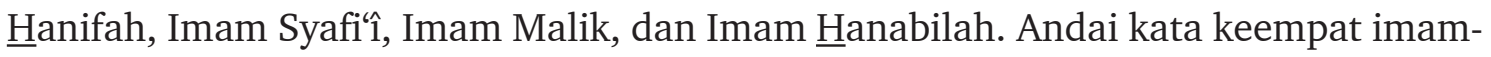
imam mazhab tersebut lahir setelah masa kodifikasi hadis dapat diasumsikan mereka tidak mungkin menjadi mujtahid-mujtahid mutlak seperti yang dikenal saat ini. Hal itu muncul dikarenakan mereka tidak bebas dalam menggunakan sumber daya hadis yang ada karena adanya hirarki dalam penggunaan kitab-kitab hadis. Walaupun belakangan diketahui bahwasanya kitab al-Muwatta' karya Imam Malik banyak memuat konten hadishadis dha'̂ff pernah dijadikan sebagai kitab undang-undang negara pada masa khalifah 'Umar ibn 'Abd al-'Azîz.

Bagaimana mungkin akan lahir mujtahid mutlak selain imam-imam mazhab yang telah disebutkan bila harus mengikuti pola hierarki yang terdapat di dalam kutub al-sittah. Kitab Shahîh $\underline{h}$ al-Bukhârî yang disebut sebagi kitab hadis, akan tetapi sangat bercorak fikih terutama tema-tema di dalam kitabnya menyerupai dengan tema-tema fikih. Hal tersebut menyulitkan fukaha belakangan untuk berijtihad disebabkan oleh patron kitab hadis merujuk pada kitab-kitab yang terdapat di dalam kutub al-sittah. Dengan kata lain, ijtihad yang harus dilakukan harus merujuk pada tema-tema pembahasan yang terdapat pada kutub al-sittah terutama mereka yang berada pada hierarki pertama. Kitab al-Muwatta' tidak mungkin akan diakui sebagai undang-undang negara pada masa khalifah Umar ibn Abd al-Azîz bila lahir pasca era kodifikasi hadis. ${ }^{8}$ Hal tersebut disebabkan hasil penelitian belakangan kitab ini banyak memuat hadis-hadis da'if. Akan tetapi, Imam Malik menyusun kitab tersebut dengan kebebasan yang tinggi tanpa harus merujuk pada hierarki kitabkitab hadis yang sudah ditetapkan membuat al-Muwatta' tetap eksis sampai kini. Kitab al-Muwatta' dipandang sebagai kitab fikih ketimbang sebagai kitab hadis, sehingga kritikan atau koreksi akan mudah ditujukan kepada kitab ini. ${ }^{9}$

Kebebasan dalam menggunakan sumber-sumber hadis sangat diperlukan dalam

${ }^{7}$ Christopher Melchert, Brown, and the Others, The Canonization of al-Bukhari and Muslim: Formation and Function of Sunni (Latin Capital Letter with Dot Below) Hadith Canon (Cambridge: Cambridge University Press, 2008), h. 526-528.

${ }^{8}$ Jonathan E. Brockopp, "Rereading the History of Early Maliki Jurisprudence," dalam Journal of the American Society (April-June 1998), h. 118.

${ }^{9}$ Ahmed El Shamsy, "Al-Shafi‘s Written Courpus: A Source-Critical Study," dalam Journal of American Society 132.2 (April-June 2012), h. 199-220. 
berijtihad adalah tidak bijak bila membatasi penggunaan hadis dalam berijtihad hanya pada kitab-kitab hadis tertentu yang dianggap paling sahih. Kitab Shahîh $\underline{h}$ al-Bukhârî selain menggunakan pola-pola fikih juga memberikan penjelasan terhadap hadis-hadis Nabi yang terdapat di kitabnya. Hal tersebut menimbulkan dilema tersendiri bagi fukaha dalam memandang kitab ini, apakah sebagai kitab hadis atau sebagai kitab fikih. Sebaiknya kitab-kitab yang terdapat di dalam kutub al-sittah dipandang sebagai kitab fikih bukan kitab hadis, sehingga tidak menutup diri dari kritikan. Lihat saja kitab al-Muwatta' ketika dipahami sebagai kitab fikih maka ulama diberi kebebasan untuk melakukan evaluasi terhadap kitab tersebut. Walaupun diakui banyak memuat hadis-hadis da'if faktanya kitab ini telah mampu membuktikan sebagai kitab undang-undang negara. Kutub alsittah yang dikenal saat ini merupakan refleksi dari pengaruh berbagai entitas baik itu penguasa maupun dominasi ulama hadis yang ingin dianggap sebagai pihak yang lebih powerful dibandingkan dengan ahli ra'yun.

Dimensi transsendental yang terdapat dalam kutub al-sittah memasung kreativitas ulama dalam berijtihad karena hanya harus merujuk kepada hadis-hadis yang terdapat di dalamnya. ${ }^{10}$ Dapat dipahami kenapa ulama Mu'tazilah hanya mengakui hadis mutawatir sebagai bagian dari hujjah mereka, disebabkan hanya sedikit hadis-hadis yang mendukung paham rasionalitas mereka. Tema-tema pembahasan yang terdapat di dalam kutub alsittah secara implisit ingin mengarahkan umat Islam hanya fokus kepada aktivitas ibadah mahdhah. Hadis-hadis yang bisa membuat masyarakat kritis terhadap kedudukan penguasa sangat jarang berada pada level kesahihan yang tinggi. Ini menyulitkan beberapa kajian fikih yang sangat tertinggal karena bisa berbenturan dengan kepentingan penguasa. Kajian tentang fikih Siyasah (fikih politik) adalah contoh betapa tertinggalnya pembahasan tentang hal ini karena selama berabad-abad lamanya tidak digarap secara serius. Pembahasan tentang Siyasah akan bersinggungan dengan kepentingan penguasa, hal tersebut bisa menjadi masalah bagi ulama hadis yang menempatkan hadis-hadis tentang suksesi berada pada level utama. Karena pasca Khulafâ al-Râsyidîn tidak ada lagi ada penguasa di dalam sejarah Islam yang benar-benar sebagai khalifah melainkan memerankan sebagai penguasa absolut yang memerintah secara turun temurun. Tidak pembahasan di dalam fikih-fikih Siyasah tentang pengaturan durasi kekuasaan seorang khalifah, sistem penggajian khalifah / sultan, maupun batasan kekuasaan seorang penguasa. Penguasa sangat berkepentingan terhadap kelanggengan kekuasaannya, tentu saja hanya ada instrumen yang membuat umat Islam tidak mengkrtik status qou yang sudah eksis berabad-abad lamanya. Instrumen hadis yang menekankan aspek ibadah ritual sebagai kesalehan yang tinggi membuat masyarakat Muslim apatis kontrol terhadap penguasa.

\footnotetext{
${ }^{10}$ Richard Bernstein, "The Uneasy Tensions of Immanence and Transcendence," dalam International Journal of Politics, Culture and Society 21.1-4 (December 2008), h. 11-16.
} 
MIQOT Vol. XXXVIII No. 1 Januari-Juni 2014

\section{Analisis}

Sejarah hukum Islam dalam memandang hadis sebagai sumber istinbâth hukum

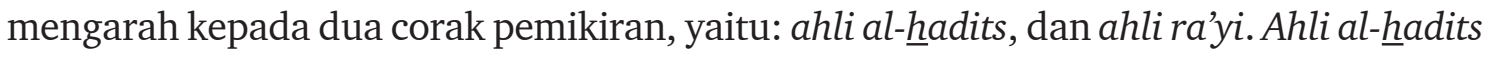
berpendapat bahwasanya hadis merupakan sebagai bayân al-Qur'an yang cenderung lebih mengutamakan lafaz nash hadis dari pada mencari 'illat yang mendasari munculnya lafaz tersebut. Sedangkan menurut ahli ra'yi berpendapat bahwasanya hukum syariah itu secara makna harus bisa dicernah oleh akal. Sebab itu, apabila suatu lafaz nash yang kurang jelas secara makna maka harus digunakan instrumen-instrumen yang ada di dalam fikih; qiyâs dan ijmak, ${ }^{11}$ merupakan metode yang disepakati oleh semua ulama fikih. Akan tetapi dalam perkembangannya ada beberapa metode ijtihâd yang membedakan antara satu ulama fikih dengan yang lainnya, seperti metode istihsân Imam Hanafi, metode istishhâb Imam Syafi î, maupun metode mashlahah dan amal ahli Madinahnya Imam Malik. ${ }^{12}$

Menurut Muhammad Khudari Bek bahwasanya beberapa hal yang menjadi faktor kemandegan berijtihad atau munculnya taklid disebabkan oleh masalah politik terutama setelah kejatuhan kota Baghdad oleh Hulagu Khan 656 H dari Mongol yang menyebabkan turunnya pamor Dinasti Abbasyiah sebagai simbol pemersatu umat Islam sehingga yang muncul adalah semangat sekterian dari berbagai bangsa di kalangan umat Islam. Terputusnya hubungan komunikasi antara ulama-ulama di dunia Islam, hal ini sering digambarkan bagaimana antara ulama satu wilayah sering mengadakan rihhlah dalam rangka mematangkan ilmu dan tukar menukar informasi di bidang keilmuan, seperti yang dilakukan oleh Imam Syafiî sehingga menghasilkan qaul jadîd merevisi pendapatnya yang terdahulu di dalam kitab al-'Umm (abad ke-2 H). Kemudian terputusnya hubungan antara umat Islam dengan kitab-kitab utama ulama-ulama klasik. Hal ini disebabkan ketika penaklukan bangsa Mongol banyak sekali buku-buku klasik yang dibakar sehingga membuat hubungan dengan karya-karya ulama klasik menjadi terputus sehingga banyak dari ulama-ulama berikutnya hanya melakukan ikhtishâr terhadap karya-karya ulama-ulama klasik yang ada karena kurangnya karya-karya pembanding akibat dari pembakaran buku-buku pada masa penaklukan bangsa Mongol tersebut. ${ }^{13}$ Lebih lanjut al-Jabiri mengatakan bahwasanya salah satu kemandegan berpikir di dunia Islam disebabkan pola pemikiran Islam Mashriqî (Timur) cenderung mendekatkan serta melibatkan dengan poros kekuasaan sehingga corak pemikiran yang berkembang mengambarkan warna pemikiran penguasa ketika itu seperti yang terkenal dalam peristiwa mihna. Apabila tidak mendapat dukungan dari penguasa akan sulit sekali untuk berkembang. Dengan demikian, corak pemikiran Islam Mashriqî kurang membumi hal ini berbeda dengan corak pemikiran Islam Maghribî

\footnotetext{
${ }^{11}$ Muhammad al-Khudharî Bek, Tarîkh al-Tasyri` al-Islâm (Beirut: Dâr al-Kutub alIslâmiyah, t.t.), h. 168-169.

${ }^{12}$ Abd al-Wahab Khallâf, Sejarah Pembentukan dan Perkembangan Hukum Islam, Wajidi Sayadi (Jakarta: RajaGrafindo Persada, 2002), h. 73-75.

${ }^{13}$ al-Khudharî Bek, Tarîkh al-Tasyri' al-Islâm, h. 312-317.
} 
(Andalusia) yang berusaha melepaskan diri dari pengaruh penguasa agar lebih bebas di dalam berijtihad dan terbukti memberi pengaruh yang besar dalam kebangkitan ilmu pengetahuan (Renaissance) di Eropa. ${ }^{14}$ Di samping itu berkembang juga pendapat yang menyatakan bahwasanya sebagian fukaha memandang hasil ijtihâd yang dilakukan oleh imam-imam mazhab wajib diikuti bagaikan nash yang tidak bisa berubah, hal tersebut membuat fukaha tersebut tidak maksimal menggunakan nalarnya. ${ }^{15}$ Sementara itu Taha J. al-Awânî mengatakan pasca berakhirnya generasi sahabat pada tahun $99 \mathrm{H}$ maka generasi pertama abad ke-1 H di antaranya 'Umar bin 'Abd al-Azîz, Ibn Sirin, dan Hasan Basri generasi ini mendapat keuntungan yang besar karena mereka langsung belajar dengan generasi sahabat. Kemudian pada abad ke- $2 \mathrm{H}$ merupakan lahirnya imam-imam mazhab sehingga karya-karya mereka yang monumental tersebut mendapat penghormatan yang berlebihan dari generasi-generasi selanjutnya yang kurang bersemangat untuk berijtihad lagi karena merasa karya-karya tersebut dapat menjawab semua persoalan hukum di masyarakat. ${ }^{16}$ Ada juga yang berpendapat sebab kemandegan berijtihad di dalam fikih dimulai setelah dilakukan kodifikasi terhadap kitab-kitab fikih yang dilakukan oleh imamimam mazhab walaupun hal tersebut memiliki dampak positif untuk memudahkan umat Islam dalam mempelajari fikih akan tetapi juga memiliki dampak negatif karena setelah kodifikasi tersebut umat Islam merasa tidak perlu lagi berijtihad. ${ }^{17}$

Sekarang permasalahannya apakah sebab-sebab taqlid atau kejumudan hanya memang itu sebagai mana yang telah disebutkan di atas. Ada satu hal yang selama ini kurang mendapat perhatian dari kalangan akademisi yaitu dari sisi hierarki Kutub alSittah yang begitu kuat otoritasnya terbukti pasca legalitasnya di abad ke-4 H hampir tidak ada lagi lahir mujtahid-mujtahid mutlak selevel dengan imam-imam mazhab, abad tersebut dipandang sebagai awal tertutupnya pintu ijtihad di dalam Islam. ${ }^{18}$

Hierarki Kutub al-Sittah terdiri dari Shahîh al-Bukhârî (194 H), Shahîh $\underline{h}$ Muslim (206 H), Sunan Abî Dâwud (224 H), Sunan al-Nasâi (215 H), Sunan al-Tarmizî (279 H), dan Sunan Ibn Mâjah (273 H) mulai diakui legalitasnya di kalangan ulama mulai abad ke-4 H. ${ }^{19}$ Pada awalnya berguna untuk memberikan penyeleksian hadis-hadis yang dikategori-

${ }^{14}$ Muhnammad 'Âbad al-Jâbirî, Nahnnu wa al-Turâs (Kairo: Markaz al-Tsaqâfî al-'Arabî, 1993), h. 40.

${ }^{15}$ Farouq Abu Zaid, Al-Syarî́at al-Islâmiyyah bayn al-Muhâfizîn wa al-Mujaddidîn, terj. Husain Muhammad (Jakarta: P3M, 1986), h. 49.

${ }^{16}$ Thâhâ J. al- 'Awânî, Taqlid and the Stagnation of the Muslim Mind (t.t.p.,: American Journal of Islamic Social Science Volume. 8, No. 3, 1991), h. 8-9.

${ }^{17}$ Amir Syarifuddin, Ushul Fiqh (Jakarta: Kencana Prenada Media Group, 2009), h. 37.

${ }^{18}$ Mustafâ Ahmad Al-Zarqâ', Al-Madkhal al Fiqhi al-'Am (Damaskus: Mathabi' Alif Ba alAdib, 1967), h. 176.

${ }^{19}$ Susunan hierarki Kutub al-Sittah yang disebutkan di atas masih ikhtilaf di kalangan ulama hadis, pada level hirarki kitab-kitab hadis sampai level ke-lima hampir tidak ada perbedaan yang berarti. Akan tetapi ketika memasuk kitab hadis yang ke-6 mayoritas ulama menempatkan Sunan ibn Mâjah sebagai kitab yang ke-6, dan orang yang pertama sekali menempatkannya ialah Abû al- 


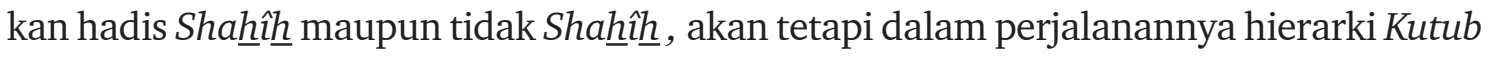
al-Sittah ini menjadi semacam batu sandungan bagi perkembangan ijtihad di kalangan ulama khususnya fikih. Hal tersebut dapat dibuktikan dengan lahirnya imam-imam mazhab dalam fikih ketika hierarki Kutub al-Sittah ini belum terlegalkan seperti sekarang ini. Dampak negatif dari otoritas yang begitu besar dari hirarki Kutub al-Sittah ini mempengaruhi kreativitas ulama dalam menetapkan suatu hukum. Kitab-kitab fikih ada sebelum terbentuk legalitas formal Kutub al-Sittah dikategorikan sebelum abad ke-4 H, di antaranya al-Risâlah dan al-'Umm karya Imam Syafi'i (150-204 H), al-Mabsûth karya Imam Hanafi (lahir tahun $80 \mathrm{H})$, al-Muwaththa' karya Imam Malik (93-179 H). Karya-karya tersebut menjadi referensi utama dalam kajian fikih, sehingga hampir bisa dipastikan seseorang yang mendalami fikih pastilah mengetahui tentang kitab-kitab utama dalam fikih di atas.

Nuansa hirarki Kutub al-Sittah menyoroti kitab Shaḩ̂h hal-Bukhârî cenderung berorientasi

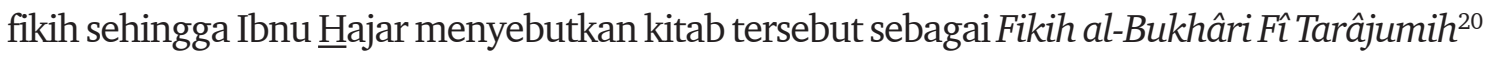
yang mengutamakan hadis-hadis yang berdimensi ibadah wajib, ternyata memberikan kontribusi yang kurang baik bagi perkembangan keilmiahan pada masa-masa berikutnya. Ditambah lagi adanya kecurigaaan intervensi dari penguasa terutama dari Dinasti Umawiyyah yang sangat berkepentingan untuk mengamankan posisi dinastinya yang awal pendiriannya dianggap illegal. Karena $\mathrm{Mu}^{\prime}$ awiyah menyadari tingkat acceptability sangat kurang dibanding 'Ali bin Abî Thâlib. Karena itu pihak Mu'awiyah sangat membutuhkan sosok sahabat yang dapat mengimbangi reputasi 'Ali. ${ }^{21}$ Sosok Ibn 'Umar sangat cocok untuk hal ini, di samping itu Ibnu 'Umar adalah sahabat yang dianggap netral dalam pertikaian politik antara Ali dan Mu'awiyah, sahabat-sahabat yang netral tersebut dipandang Mu'awiyah sebagai pihak yang bisa memperkuat legitimasinya. Ibn 'Umar juga dianggap sebagai rijâl al-hadits paling diakui ke-siqqahan-nya oleh ulama-ulama hadis merupakan icon sahabat yang sengaja diciptakan oleh dinasti Umawiyyah yang menampilkan sosok Ibn 'Umar yang sangat bersahaja dengan meniru semua tindakan, cara berjalan, sampai yang sekecilkecilnya yang dilakukan oleh Nabi Muhammad SAW. Kesederhanaan Ibn 'Umar serta sikapnya yang tidak mau terlibat pada politik praktis membuat Ibn 'Umar sebagai sosok utama yang dijadikan rujukan dalam meriwayatkan hadis. Di samping itu adanya nuansa politik dalam penyusunan hierarki Kutub al-Sittah dapat dibuktikan dengan sedikit sekali memasukkannya hadis-hadis yang diriwayatkan dari 'Ali bin Abi Thâlib, Ja'far bin Abi Thâlib atau $\underline{\text { Hasan }}$ bin 'Ali karena mereka dianggap sebagai lawan politik dinasti Umawiyyah. ${ }^{22}$

Fadhl Muhamamad ibn Tâhir al-Maqdîsi, Lihat Abû al-Fadhl Muhammad ibn Tâhir al-Maqdîsi, Shurûth al-A'immat al-Sittah (Beirut: Dâr al-Kutub al-'Ilmiyah, 1984), h. 24.

${ }^{20}$ Ibn Hajar al-Asqalâni, Hady al-Sârî, 8-14. Abû Bakar Muhammad ibn Mûsâ al-Hâzimî, Shurût A'Immat al-Khamsah (Beirut: Dâr al-Kutub al-"Ilmîyah, 1984), C. I, h. 68.

${ }^{21}$ Al-Minqarî, Nasr ibn Muzahîm, Waq'at Siffin. Edited by 'Abd al-Salâm Muhammad Harûn, (Beirut: Dâr al-Jîl, 1990), h. 82.

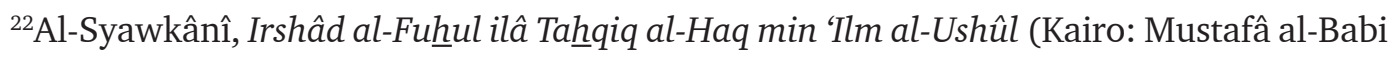
al-Halabî wa-Awlâduh,1973), h. 70. 
Keputusan Muawiyah untuk membaiat anaknya Yazid sebagai putra mahkota penggantinya kelak menimbulkan kontroversi di kalangan ulama. Apakah memang Islam telah mengatur dalam masalah suksesi ini. ${ }^{23}$ Kenyataannya Nabi tidak pernah mempermasalahkan kepemimpinan yang ada di bangsa Arab ketika itu dipegang secara turun menurun tanpa adanya proses pemilihan. Hal tersebut sudah berlaku di kalangan pemimpin suku-suku Arab ketika itu. Bahkan pemegang kunci Ka'bah selalu dipegang oleh keturunan Bani Hasyim (keturunan Nabi Muhammad) secara turun temurun. Ada pula legitimasi nash yang memberikan tempat khusus untuk menjadi pemimpin itu adalah berasal dari suku Quraisy. Hal itu menimbulkan asumsi bahwasanya Nabi Muhammad SAW berusaha mempertahankan kebiasaan pra-Islam yang cenderung tidak mencerminkan prinsip musyawarah dan mengkultuskan suku bangsa tertentu. Sekilas hal tersebut melanggar sistem egaliter di dalam Islam yang bisa menimbulkan masalah. Karena itu, sikap Muawiyah mendirikan dinasti atas nama keturunan sebenarnya adalah salah satu dari sunnah yang berlaku semenjak pra-Islam tanpa ada koreksi dari Nabi sendiri. Itu mungkin alasan mengapa sebagian besar sahabat tidak mempermasalahkan perubahan sistem musyawarah yang berlaku pada masa Khulafâ al-Râsyidîn menjadi sistem kerajaan.

Dalam kurun waktu satu abad banyak hal yang dibuat oleh Dinasti ini dalam menyebarkan Islam ke negeri yang jauh bahkan menjadi pionir dalam membangun peradaban Islam. ${ }^{24}$ Kisah sukses Dinasti Umawiyyah membuahkan suatu pertanyaan mendasar apakah di dalam Islam itu lebih menonjolkan aspek tercapainya maslahat umat atau lebih mengedepankan pada cara untuk mencapai maslahat itu sendiri. Hal ini penting untuk dikaji karena cara Muawiyah yang dipandang kurang baik bughat terhadap pemerintahan 'Alî ternyata ketika berkuasa dapat mengejewantahkan kestabilan politik, kemakmuran dan peradaban yang tinggi. ${ }^{25}$

Legalitas formal Kutub al-Sittah tidak terjadi secara simultan akan tetapi mengalami metamorfosa sehingga mencapai bentuknya di awal abad ke-4 H. Karena itu susunan hierarki dari kitab-kitab hadis dapat dipolakan menjadi empat bentuk penulisan hadis, yaitu: sunan, musannaf, jâmi' dan musnad. Tiga model pertama tampaknya sangat berpola fikih yang menandakan kuatnya pengaruh fikih ketika itu. ${ }^{26}$ Karena itu susunan hierarki

${ }^{23}$ Agak aneh bila tidak ada riak politik yang timbul akibat penobatan Yazid sebagai putra mahkota Dinasti Umawiyyah, kalaupun ada sudah diredam dengan kekuatan politik yang dimilikinya. Lihat Muhammad Abû Zahrah, Malik: Hayât wa Arâ'ah al-Fiqhiyyah (Kairo: al-Angelo al-Micriyyah Bookstore, 1946). Lihat juga 'Abd al-Halim al-Jondi, Malik ibn Anas (Kairo: Dâr al-Ma'ârif, 1983).

${ }^{24}$ Hodgson M, "The Role of Islam in World History. dalam "International Journal of Middle East Studies, 1(2) (1970), h. 99-123.

${ }^{25}$ Langkah politik yang dilakukan oleh Muawiyah tidak bisa hanya dilihat dari satu aspek saja, akan tetapi atmosfir ketegangan yang diciptakan masih terasa sampai saat ini. Lihat Kennedy Hug, The Great Arab Conquests; How the Spread Islam Changed the World We Live in (Portland: Da Capo Press, 2007), h. 78-89.

${ }^{26}$ Lihat Mahmud al-Tuhhân, Taysîr Mushtala $\underline{h}$ al- $\underline{\text { Hadits }}$ (Kuwait: Markaz al-Hudâ li al-Dirâsat, 1984), C. VII, h. 131-132. 
dari Kutub al-Sittah bukanlah menjadi hal yang qath'îy yang tidak boleh diganggu gugat. Penetapan hierarki di dalam Kutub al-Sittah merupakan gambaran pertaruhan masingmasing entitas yang terjadi di masa itu yang merupakan refleksi sosio kultural awal mapannya kodifikasi hadis. Hal tersebut manifestasi dari berakhirnya masa kejayaan ahli ra'yun di dalam dunia Islam. Dominasi ahli ra'yun hanya berkisar satu abad saja dalam masa kekuasaan Dinasti Abbasiah ditandai berakhirnya masa Khalifah al-Mutawakkil. Setelah itu ulama hadis semacam tidak memiliki kompetitor yang bisa mengkritik arah pemikiran konservatif mereka. Ketatnya kriteria hadis yang dilakukan oleh ahli ra'yun bukan disebabkan kurangnya keyakinan mereka terhadap hadis, akan tetapi disebabkan oleh resoures hadis yang ada kurang mendukung pemikiran mereka. Karena komposisi hadis yang diakui kesahihannya kebanyakan berkisar pada masalah-masalah yang menyangkut dengan ibadah ritual, sedangkan kajian-kajian yang berkenaan yang mengarahkan umat Islam berpikir kritis jarang sekali mencapai level tertinggi.

\section{Bias Intervensi Penguasa dalam Kodifikasi Hadis}

Kodifikasi hadis yang dilakukan di awal abad ke-2 $\mathrm{H}$ pada masa Khalifah Umar bin Abdul Azis dengan mengangkat ulama hadis yang terkenal pada masa itu Ibn Syihâb alZuhrî ${ }^{27}$ untuk untuk melakukan inventarisir hadis Nabi memiliki makna tersendiri bagi perkembangan hadis selanjutnya. Hadis bagi umat Islam sebagai kitab suci kedua setelah al-Qur'an sering dipandang sebagai bayân wahyu Allah kepada Nabi Muhammad SAW.

Kegiatan kodifikasi hadis yang awalnya merupakan inisiasi dari pihak penguasa menimbulkan konsekwensi adanya intervensi terselebung terhadap teks-teks hadis yang dapat mengganggu hegemoni kekuasaan mereka. Teks hadis tentang kepemimpinan di tangan suku Quraisy sangat masyhur disebarkan pada masa Bani Umawiyyah berkuasa. Hal tersebut dilakukan untuk memberikan legitimasi kepada suku Quraisy untuk memerintah wilayah kekuasaan yang luas. Legitimasi itu sangat diperlukan oleh Bani Umawiyyah yang juga berasal dari suku Quraisy untuk meredam pihak-pihak yang mencoba menggulingkan pemerintahan ini. Padahal teks hadis tersebut sangat bertentangan dengan prinsip-prinsip kesetaraan di dalam Islam. Alangkah naifnya bila Nabi Muhammad SAW mengajarkan sesuatu yang menonjolkan suku bangsa tertentu. Teks hadis tersebut harus dipahami dalam kerangka politik identitas yang dilakukan oleh Nabi dalam melakukan

${ }^{27}$ Merupakan ulama hadis yang dapat dipastikan cukup dekat dengan kalangan penguasa Dinasti Muawiyah karena pada masa ini sebagian dari para ulama masih menjaga jarak dengan Dinasti Umawiyyah karena masih trauma dengan perpecahan yang ditimbulkan akibat berdirinya imperium ini, seperti yang dilakukan oleh Imam Malik yang menolak dengan keras kitab alMuwaththa'-nya dijadikan sebagi undang-undang negara walaupun akhirnya pihak penguasa memaksakan untuk menjadikan kitab al-Muwaththa' sebagai kitab undang-undang negara. Tugas Imam al-Zuhrî juga menghimpun hadis-hadis yang masih diriwayatkan dalam bentuk oral transmission agar dituliskan dalam bentuk tulisan. 
konsolidasi sumber daya umat Islam agar lebih mudah untuk dipimpin dalam satu komando yang jelas. Teks hadis secara implisit menggambarkan komunitas suku Quraisy yang memiliki sumber daya yang diperlukan dalam penyebaran Islam secara menyeluruh. Tidak dapat dipungkiri icon yang diperlukan untuk memberi justifikasi legitimasi terhadap sesuatu agar menghasilkan loyalitas dari masyarakat secara luas. Fakta inisiasi kodifikasi hadis dilakukan oleh penguasa juga kegiatan-kegiatan kodifikasi hadis sangat memerlukan jaringan dan dukungan finansial dari penguasa, sehingga intervensi penguasa terhadap kegiatan tersebut tidak bisa dihindari.

Sebelum kodifikasi hadis dilakukan yang eksis di dalam masyarakat Muslim adalah sunnah, ${ }^{28}$ sunnah yang hidup ini bagi umat Islam berasal sejak masa Nabi Muhammad SAW. Sunnah yang merupakan prilaku Nabi Muhammad saw dan para sahabat yang dipraktekkan oleh generasi berikutnya. Usaha kodifikasi hadis dalam bentuk tertulis dari bentuk prilaku maupun ucapan menimbulkan penyeleksian sunnah-sunnah yang hanya memiliki kriteria yang dibuat oleh ulama-ulama hadis. Atas dasar inilah seorang Orientalis Joseph Schacht mengatakan tidak ada hadis yang benar-benar asli dari Nabi Muhammad, kalaupun ada hanya sedikit. ${ }^{29}$

Joseph Schacht mengklaim bahwasanya tidak ada data atau bukti tertulis yang merujuk adanya hadis di awal Islam mendapat respon dari ilmuwan-ilmuwan Muslim, di antaranya Fazlur Rahman, ${ }^{30}$ Muhammad Hamidullah, ${ }^{31}$ Fuat Sezgin,${ }^{32}$ dan Muhammad

${ }^{28}$ Sunnah bagi kebanyakan orientalis tidak berasal dari masa Nabi Muhammad SWA. alasannya karena sunnah yang diklaim ummat Islam pada dasar sunnah yang dibuat oleh umat Islam abad ke $3 \mathrm{H}$, hal ini ditandai dengan terlegitimasinya sunnah baru terjadi pada awal abad ke $3 \mathrm{H}$ ketika ada usaha untuk menyeleksi sunnah-sunnah yang berkembang setelah diterjemah-kan dalam batasan teks-teks hadis. Lihat Joseph Sacht, "Pre-Islamic Background and Early Development of Jurisprudence" dalam Law in The Middle East, edited by Majid Khadduri and Herbert (Liebesny: Middle East Institute, 1995), h. 28-30.

${ }^{29}$ Lihat Joseph Schacht, The Origins of Muhammadan Jurisprudence, cet. 2 (Oxford: Clarendon Press, 1959), h. 149.

${ }^{30}$ Bagi Fazlur Rahman kesalahan orientalis dalam memahami hadis hanya menyandarkan pada aspek bukti tertulis semata. Padahal kultur Arab yang berlaku pada masa itu dan tetap dipertahankan samapi sekarang ini ialah hapalan. Bagi orang Arab hapalan merupakan suatu budaya yang sudah melekat dalam diri mereka hal ini dapat dibuktikan dengan kontes hapalan terhadap syair-syair yang terpilih, apalagi al-Qur'an dan hadis yang dipercaya sebagai manifestasi petunjuk Allah melalui Nabi-Nya yang diakui memiliki nilai yang lebih tinggi dari pada karyakarya syair jahiliyah selama ini. Lihat Fazlur Rahman, Islam and Modernity (Chicago: University of Chicago Press, 1982), h. 18-22.

${ }^{31}$ Muhammad Hamidullah, "Aqdam Ta'lîfi al-Hadîts al-Nabawi-Shahîfah Hamman ibn Munabbih wa Makanatuha fî Târikh Ilm al-Hadîts," dalam Majallat al-Majma' al-Ilmi al-Arâbi 28(1953), h. 96-116, 270-281;cf. Muhammad Hamidullah, The Earliest Extant work on The Hadits: Shahîhah Hammam ibn Munabbih, comprising al-Shahîhah al-Shahihah of Abû Hurayyah, prepared for Pupil Hamman ibn Munabbih, together with an introduction to the History of the Early Compilation of hadis, (Paris: Center Culturel Islamique, 1961), dan M. Hamidullah, "Early History of the Compilation of the Hadith", dalam Islamic Literature, vol. 12, No. 3 (Lahore, 1966), h. 5-10.

${ }^{32}$ Seorang Ilmuwan Muslim asal Turki yang telah membuat semacam ensiklopedia tentang 
Mustafa al-Azami. ${ }^{33}$ Mereka sepakat tuduhan Joseph Shacht adalah keliru karena masyarakat awal Islam dalam mempraktikkan Sunnah Nabi Muhammad bukan hanya berdasarkan tulisan akan tetapi juga yang lebih penting dari itu tradisi Nabi Muhammad SAW sudah menyatu dengan prilaku kehidupan. Harus dipahami bahwasanya sosok Muhammad menjadi magnet yang luar biasa bagi masyarakat Muslim terutama bagi yang hidup semasa dengannya. Maka dari itu tidak heran tradisi (baca: sunnah) sudah menjadi bagian hidup masyarakat awal Islam yang tidak dapat dipisahkan dari mereka.

Kodifikasi hadis yang dilakukan bertujuan untuk menghimpun hadis-hadis Nabi yang berserakan di banyak daerah-daerah di wilayah jazirah Arab. Penyebaran sahabat dalam berdakwah membuat proyek pengumpulan hadis-hadis ini menjadi lebih rumit sekaligus menjadi entry point bagi ulama-ulama hadis berikutnya untuk menyeleksi hadis. Kodifikasi hadis yang dilakukan dipandang urgen untuk memelihara hadis-hadis Nabi agar tetap eksis dan dapat dipahami oleh orang-orang generasi berikutnya. Kodifikasi yang dilakukan di awal abad ke-2 $\mathrm{H}$ itu menjadi rujukan utama bagi ulama-ulama hadis di abad ke-3 H untuk melakukan verifikasi data-data hadis yang sudah dikumpulkan tersebut. Masing-masing ulama hadis membuat metodologi tersendiri untuk menentukan kevaliditasan suatu hadis.

Masalahnya selama ini metodologi yang dibuat oleh ulama-ulama hadis abad ke$3 \mathrm{H}$ hingga saat ini dipandang sebagai metode yang memiliki otoritas ${ }^{34}$ yang tidak bisa diganggu gugat. Hal inilah yang membuat sulitnya berkembang kajian-kajian keilmiahan keislaman yang dilakukan oleh akademisi Muslim sengaja membelenggukan diri mereka terhadap sesuatu yang dianggap kultus, sehingga sumber utama dalam menjalani hidup

para tabi'in dan karya-karya mereka. Tesisnya "Buhari'nin Kaynaklari” (The Sources of al-Bukhâri), berpendapat bahwasanya tradisi oral dan tulisan hadis-hadis yang diriwayatkan oleh Sha $\underline{h} \underline{\hat{h}}$ al-Bukhârî berasal dari abad ke-7 M. Fuad Sezgin juga adalah seorang llmuan asal Turki yang meragukan Columbus yang pertama sekali menemukan benua Amerika menurutnya Benua Amerika pertama sekali ditemukan oleh umat Islam yang ditandai dengan peta yang digunakan oleh Columbus berasal dari tulisan berbahasa Arab, lihat Fuat Sezgin, "Islam History of Science and Technology Needs to Speak", di dalam Turkish Daily News, (27 Desember 2008).

${ }^{33}$ M. M. Azami, Studies in Early Hadith Literature: With a Critical Edition of Some Early Texts (Indianapolis: American Trust Publication, 1992), h. 25.

${ }^{34}$ Dalam masalah otoritas ini Mohammed Arkoun menyoroti bagaimana skema otoritas yang terbentuk dalam sejarah Islam terutama dilakukan oleh para qadhi yang diberi tugas oleh penguasa Muslim dalam menyelesaikan banyak kasus, walhasil keputusan-keputusan qadhi tersebut seiring perkembangan waktu memiliki otoritas dalam menafsirkan nash al-Qur'an dan hadis. Secara eksplisit dia memaparkan bahwasanya otoritas mutlak dalam menafsirkan nash hanya pada Allah sehingga ia menganjurkan susunan kaedah-kaedah yang sudah terbentuk selama ini harus direvisi sesuai dengan dinamika masyarakat Muslim. Lihat Mohammed Arkoun, The Concept Of Authority in Islamic Thought: Lâ Hukma Illâ Lillah", in The Islamic World: From Classical to Modern Time, Edited by C.E.Bosworth, Charles Issawi, Roger Savory and A.L Udvitch (London: The Darwin Press), h. 31-54. 
ini bagi umat Islam al-Qur'an dan Hadis menjadi kaku dan kurang bisa menciptakan solusi sosial yang jitu dalam menjawab segala tantangan zaman. ${ }^{35}$

Metode dalam menentukan hierarki hadis vertikal bisa jadi cocok dalam kurun waktu tertentu akan tetapi boleh jadi pada masa sesudahnya kurang relevan dalam konteks kekinian. Imam al-Bukhârî misalnya membuat kriteria hadis yang masuk dalam kitabnya harus berjumpa antara guru dan murid, ${ }^{36}$ walaupun kriteria tersebut dipandang paling sahih oleh kebanyakan ulama-ulama hadis semasanya atau beberapa abad setelahnya. Kitab Shaĥh $\underline{h}$ al-Bukhârî ini juga dipandang sebagai kitab hadis yang berwajah fikih karena di dalamnya memuat hadis-hadis berdasarkan tema-tema yang belakangan dikenal di dalam tema-tema fikih.

Dari itu tidak heran setelah Imam Syafiî̀ dengan kitab al-Risâlah hampir tidak ada lagi yang original dalam membuat sistematika hukum Islam yang berdasarkan nash. Dikarenakan adanya hierarki ini membuat para ulama kesulitan dalam merumuskan formulasi baru hukum Islam. Karena banyak energi terkuras memikirkan formulasi hukum Islam baru tidak efisien karena memaksakan ijtihad fikih terperangkap dengan kultus hirarki hadis. Padahal bila diteliti dengan lebih seksama sebenarnya masing-masing kitabkitab hadis memiliki kluster hukum dan memiliki kekhasan tersendiri. Adalah benar bila dikatakan kitab Shahîh al-Bukhârî sangat valid bila berbicara dalam masalah ibadah mahdha (khusus) akan tetapi hampir tidak ada membicarakan masalah-masalah yang menyangkut suksesi kepemimpinan. Hal inilah yang membuat asumsi bahwasanya penempatan kitab Shahîh al-Bukhârî sebagai kitab hadis utama pada awal kodifikasi hadis di awal abad ke $2 \mathrm{H}$ pada masa Khalifah 'Umar bin 'Abd al-Azîs ${ }^{37}$ memiliki bias politik. Karena proses kelahiran Dinasti Ummayyah ini dianggap illegal dan dituding sebagai pihak yang memberikan kontribusi perpecahan abadi di dalam Islam antara Sunni dan Syi'ah, serta yang menyebabkan lahirnya kelompok teologi Khawarij. Tentu sangat dimaklumi bahwasanya dinasti ini perlu adanya pengakuan dari ummat Islam maka dari itu klasifikasi hierarki kitab hadis

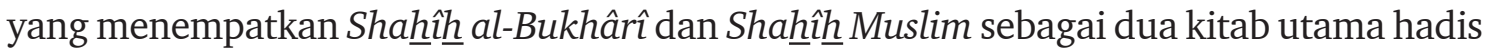
memiliki aspek penonjolan terhadap kedua kitab tersebut. Karena dua kitab utama dalam bidang hadis itu kebanyakan isinya masalah-masalah ibadah khusus yang menyangkut dengan rukun iman dan rukun Islam mengarahkan masyarakat Muslim untuk lebih memberikan porsi yang lebih besar dalam masalah-masalah ibadah sehingga lambat laun tidak memikirkan hal-hal yang bisa mengganggu hegemoni kekuasaan Dinasti Ummayyah.

\footnotetext{
${ }^{35}$ Lihat Mohammed Arkoun, The Concept of Authority in Islamic Thought (London: Oxford University Press, 2010), h. 42-44.

${ }^{36}$ Metode ini dipandang paling kuat dalam menyeleksi hadis menjadi sahih, banyak ulama hadis yang merujuk pada metode Bukhârî ini.

${ }^{37}$ Walaupun sebahagian ulama menganggap bahwasanya Khalifah 'Umar bin 'Abd al-Azis sebagai Khalifah terbaik dari dinasti Umawiyyah bahkan ada yang menganggapnya sebagai Khalifah ke 5 dalam lingkup Khalifah al-Nubuwwah akan tetapi bukan berarti kebijakan politiknya tidak

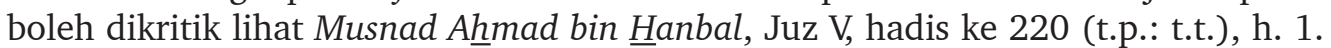




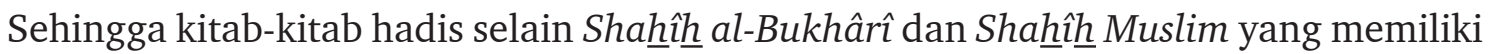
matan yang bisa membuat orang untuk berpikir kritis yang menyangkut sosial, ekonomi, dan politik dianggap level yang rendah.

Tulisan ini bukan untuk mempertanyakan eksistensi hadis yang memang menjadi rujukan utama setelah al-Qur'an bagi umat Islam. Akan tetapi penelitian ini bermaksud untuk lebih menghargai hadis yang berasal dari sumber yang sama agar diperlakukan sama. Artinya bila selama ini hierarki kitab-kitab hadis terutama kutub al-sittah yang sudah menjadi standar bagi ummat Islam memiliki otoritas yang sangat kuat agar dapat dibuat tanpa kasta. Dengan demikian tidak ada perbedaan kelas antara kitab Shahîh $\underline{h}$ al-Bukhârî dengan Sunan Abû Dawud, dan Sunan Ibn Majah. Kenyataannya dengan susunan vertikal secara hierarki tersebut membuat para ulama kesulitan dalam berijtihad karena banyak permasalahan umat Islam setelah berabad-abad pasca kodifikasi hadis kurang cocok diselesaikan dengan menggunakan hadis Shaikhâni tetapi ditemukan jawabannya di kitab-kitab hadis yang level bawah dari hierarki tersebut menjadi kurang memiliki otoritas yang kuat.

Bahkan sudah saatnya para ulama memperlakukan hadis sebagai rujukan dalam menetapkan hukum secara adil tanpa membedakan hierarki maupun perbedaan teologi. Artinya harus menghilangkan dikotomi hadis Sunni dan Syiah karena sama-sama berasal dari Nabi yang sama. Lagi pula susunan hierarki kitab-kitab hadis yang selama ini dikenal tidak memiliki otoritas absolut, karena awalnya masing-masing ulama memiliki hierarki tersendiri dalam menentukan kitab-kitab hadis yang bagaimana yang menempati posisi puncak maupun yang paling rendah. Larangan untuk menulis hadis bukan saja berlaku pada masa Nabi Muhammad bahkan sampai pada masa sahabat, seperti yang terjadi pada masa 'Umar bin Khaththab. Setelah menaklukan wilayah Irak khususnya di wilayah Kufah telah ada usaha-usaha untuk menuliskan lafaz hadis. Dengan wilayah yang cukup jauh dari Madinah dikhawatirkan dapat mencampurkan antara al-Qur'an dan hadis. ${ }^{38}$ Walaupun dalam kasus-kasus tertentu ada di antara para sahabat yang memiliki catatan sendiri dalam tentang hadis-hadis tententu

Selama ini metode isnâd ${ }^{39}$ yang dilakukan oleh ulama-ulama abad ke- $3 \mathrm{H}$ sudah

${ }^{38}$ Umar bin Khaththab melarang praktik Sunnah baik itu secara oral maupun tulisan karena akan menimbulkan kompetisi yang kurang baik dalam penulisan antara al-Qur'an dan hadis yang disinyalir asal muasal munculnya hadith qudusî yang mencantumkan lafaz Qâla Allâhu (Allah berfirman), lihat dalam Nabia Abbott, Studies in Arabic Literary Papyri, II: Qur'anic Comentary and Tradition in Early Development of Written Tradition (Chicago: Chicago University Press, 1967), h. 11.

${ }^{39}$ Metode yang penting dalam Ilmu Rijâl al-Hadith merupakan cabang yang penting. Yang

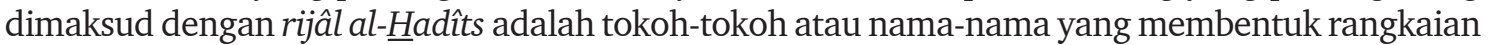
sanad atau dengan istilah lain rawi hadis. Ilmu Rijal al-Hadits dibagi menjadi dua bagian, yaitu

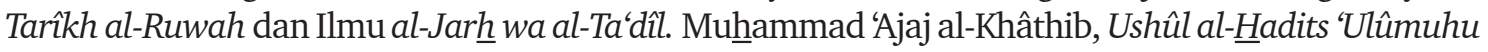
wa Mushthalahnuhu (Beirut: Dâr al-Fikr, 1989), h. 203. 
dianggap hal tidak bisa ditawar lagi padahal bila dicermati dengan seksama terkadang matan hadis yang dipandang sahih terkadang kurang memenuhi rasa keadilan maupun logika sehat. Misalnya hadis yang mempertanyakan keislaman Abu Thâlib sangat masyhur disebarkan akan tetapi kurang sekali hadis yang memunculkan bagaimana sepak terjang Abû Sofyân ayah Mu'awiyah pendiri Dinasti Mu'awiyah ketika memerangi Nabi Muhammad dan para sahabat dalam menyebarkan Islam dan keislaman Abû Sofyân sendiri diragukan karena faktor keterpaksaan. Ketika fath al-Makkah (penaklukan kota Makkah) ultimatum Nabi Muhammad kepada penduduk Makkah apabila ingin selamat harta dan jiwanya berlindung di Baitullah dan rumah Abû Sofyân dengan demikian ketundukan Abû Sofyân kepada Nabi Muhammad lebih cenderung disebabkan menyelamatkan diri dan aset-asetnya dari kekuatan Islam yang tidak mungkin dilawannya lagi. Sementara Abu Thâlib yang selama hidupnya membela Islam dan Nabi Muhammad sering sekali disudutkan bahkan dituduh sebagai seorang yang kafir.

Abu Rayyah seorang peneliti hadis yang sering dituduh sebagai ingkar sunnah mempertanyakan kredibilitas seorang sahabat yang bernama Abû Hurairah, padahal dia sangat mengakui hadis Nabi Muhammad SAW sebagai rujukan utama setelah al-Qur'an yang diinginkannya adalah kemurnian dari hadis itu sendiri. Karena baginya tidak semua sahabat itu adil, bila demikian maka secara otomatis menyamakan kedudukan mereka dengan Nabi Muhammad SAW yang di mata umat Islam sebagai seorang yang ma'sûm yaitu terlepas dari dosa. Abû Hurairah juga dikritik karena tidak meriwayatkan hadis ketika pada masa Khalifah Abû Bakar dan 'Umar, mereka berdua dikenal sangat keras dan selektif dalam menerima hadis yang tidak didengarnya sebelumnya bahkan sahabatsahabat yang dikenal kewarakannya disuruh bersumpah dan membawakan saksi ketika meriwayatkan hadis, seperti yang dialami oleh 'Ali bin Abi Thalîb, dan Abû Mûsa saja diminta sumpah ketika meriwayatkan hadis pada masa kedua khalifah di atas dan 'Utsmân bin Affân juga pernah menyampaikan tidak boleh seseorang meriwayatkan hadis yang tidak diriwayatkan pada masa Khalifah Abû Bakar dan 'Umar bin Khaththab. ${ }^{40}$

Fatima Mernisi juga mengkritik hadis yang diriwayatkan dari sanad Abû Hurairah yang sangat tendensius dalam merendahkan dan menyudutkan kaum wanita dan ini bertolak belakang dengan perilaku Nabi yang sangat menghargai kaum wanita. Karena dari itu Fatima Mernisi mengajukan hadis pembanding dari sumber 'A'isyah yang matanmatan hadis yang menyangkut tentang wanita. Karena menurutnya perilaku Nabi Muhammad yang sangat menghargai egaliter di dalam Islam ternodakan oleh orangorang yang masih membawa budaya Misogis terhadap wanita. ${ }^{41}$

${ }^{40}$ Lihat Abu Rayyah, Adhwa' Ala Sunnah wal Muhammadiyah au Difầu 'ala al-hadith (Cairo: Dâr al-Ma`ârif, 1119 H ), 26. Di sini digambarkan bagaimana Abu Hurairah tidak pernah dikenal meriwayatkan hadis nabi ketika pada masa khalifah Abu Bakar dan Umar bin Khattab yang dikenal sangat selektif dalam menerima hadis dari sesama sahabat.

${ }^{41}$ Fatima Mernissi, The Veil and the Male Elite: A Feminist Interpretation of Women's Rights in Islam, translated by Mary Jo Lakeland (New York: Basic, 1991), h. 1. 


\section{Dinamika Perkembangan Fikih}

Fikih tidak bisa dipisahkan dengan hadis oleh karena itu usaha yang dilakukan oleh Wael B. Hallaq bahwasanya hukum Islam itu tetap dinamis dengan ijtihad-ijtihad baru dari para ulama sepanjang zaman ${ }^{42}$ dipertanyakan oleh Calder. Calder mempertanyakan apa sebenarnya hukum Islam itu masih ada yang original, baginya semenjak abad ke 10 sampai abad ke 19 sama sekali tidak ada hukum Islam yang original lahir dari metodologi ulama dan menggunakan sumber-sumber Islam. ${ }^{43}$ Karena menurutnya hukum Islam selama 9 abad hanya mengadopsi hukum-hukum dari luar paling tidak hanya berkutat pada masalah-masalah yang sudah dibahas ulama-ulama sebelum abad ke 5 karena produk-produk hukum yang dihasilkan oleh ulama-ulama mandeg dimulai setelah imam Syafiîi dengan al-Risâlah. Hal ini dapat dilihat dari usaha Qanûn al-Ahkkâm Sulthaniyah pada masa Turki Usmani dengan mengimpor produk-produk hukum perdagangan dari Prancis kemudian diberi label dalam bahasa Arab lalu umat Islam menganggapnya sebagai hukum Islam.

Berbeda dengan Calder, Wael B. Hallaq lebih memahami bahwasanya hukum Islam itu bersifat dinamis dan berevolusi, artinya dia memahami hukum Islam merupakan produk hukum yang dipraktikkan sehari-hari dan dilegitimasi dengan ulama-ulama yang memiliki otoritas. Yang dimaksud ulama yang memiliki otoritas di sini fatwa-fatwa ulama yang membahas masalah-masalah fur'iyah dan kemudian fatwa tersebut dipraktik dalam komunitas masyarakat yang lebih besar dengan mendapatkan dukungan dari ulamaulama se zamannya. ${ }^{44}$ Walaupun Coulson menolak fatwa-fatwa individu setelah abad ke- $5 \mathrm{H}$ karena tidak memiliki otoritas keilmuan dan lebih condong kepada fatwa yang bersifat komunal. ${ }^{45}$ Bagi Wael B. Hallaq menunggu fatwa secara komunal akan memakan waktu yang lama sementara itu perubahan permasalahan sosial sangat cepat perlu direspon dengan memberikan fatwa furu؛

Memang bila dicermati tuduhan Calder bahwasanya ijtihad di dalam hukum Islam sudah tertutup ada benarnya juga di satu sisi bila merujuk pada kenyataan di dalam konstalasi

${ }^{42}$ Wael B. Hallaq, 'Was the Gate of Ijtihâd Closed?', dalam International Journal of Middle East Studies, 16 (1984), h. 3-4. dan menurut pandangan Johansen apa yang dikemukakan oleh Wael B. Hallaq pintu ijtihad tidak pernah tertutup dalam sejarah Islam hanya dalam bentuk teori bukan praktek dan tidak ada perubahan secara hukum legal, lihat B. Johansen, 'Legal Literature and the Problem of Change', in Islam and Public Law, ed. C. Mallat (London: Graham and Trotman, 1993), 29-31 (and in B. Johansen, Contingency in a Sacred Law (Leiden: Brill, 1999), h. 446-448.

${ }^{43}$ Lihat Norman Calder, Islamic Jurisprudence in Classical Era, edited by Colin Imber (Cambridge University Press, 2010), h. 14.

${ }^{44}$ Lihat Wael B. Hallaq, An Introduction to Islamic Law (London: Cambridge University Press, 2009), h. 38-40.

${ }^{45}$ Norman Calder, Islamic Jurisprudence in the Classical Era (London: Cambridge University, 2010), h. 11. 
ijtihad para ulama sampai saat ini hanya melakukan proses islamisasi terhadap produkproduk hukum yang ada. Wael B. Hallaq juga mengakui secara tersirat bahwasanya perubahan hukum Islam itu berevolusi dengan usaha yang dilakukan oleh ulama-ulama kontemporer dengan fatwa furu pada awalnya hanya usaha labelisasi keislaman. Agaknya ulama-ulama Muslim kontemporer mengakui sulit keluar dari lingkaran kejumudan yang ada selama ini. Maka langkah pertama yang dilakukan mereka dengan labelisasi keislaman atau meminjam istilah Ismail al-Faruqi dan Naquib Al-Attas "islamisasi ilmu pengetahuan" ketika sumber daya sudah memenuhi maka para ulama akan menemukan ijtihad yang original dalam menjawab segala persoalan di masyarakat, makanya Wael B. Hallaq menggunakan terminologi evolusi dalam hukum Islam. Karena tidak mungkin membuat revolusi hukum Islam Islam bila bahan-bahan dari revolusi itu berasal dari racikan luar (baca: Barat).

Bukan berarti pula mengakui pendapat Josep Schacht yang mengatakan terbentuknya hukum Islam itu dimulai pada abad ke- $3 \mathrm{H}$, hal ini disebabkan kodifikasi sunnah menjadi hadis sebenarnya diciptakan pada masa ini sehingga terbentuknya hukum Islam berawal pada abad ke- $3 \mathrm{H} .{ }^{46}$ Joseph Schacht memahami dari sisi terbentuknya teks-teks hadis yang kemudian menjadi dasar hukum. Bila demikian, bagaimana pula dengan para Nabi dari semenjak Nabi Adam sampai Nabi Musa, mereka tidak menerima wahyu Allah dalam bentuk kitab atau tulisan kecuali semenjak Nabi Musa sampai Nabi Muhammad. Konsekwensinya bila merujuk pendapat Joseph Schacht dasar terbentuknya hukum harus merujuk pada sumber yang tertulis berarti para Nabi sebelum Nabi Musa seperti Nabi Nuh, Ibrahim, dan Luth tidak membawa dan menyebarkan hukum Allah. Sedangkan salah satu fungsi utama seorang Nabi menyampaikan hukum/ aturan dari Allah kepada masyarakatnya masing-masing. Karena manusia mengenal tulisan semenjak 3200 SM dengan merujuk umur dari huruf-huruf dinding yang terdapat di dinding pyramid (heliografi) ${ }^{47}$ pada masa Mesir kuno sezaman dengan Faroh II atau Fir'aun yang menentang ajaran Nabi Musa. Kemungkinan atas dasar inilah kenapa Allah menurunkan wahyu pertama sekali dalam bentuk kitab /tulisan karena masyarakat pada masa Nabi Musa sudah mengenal tulisan sehingga alangkah naifnya bila Allah menurunkan wahyu dalam bentuk tulisan kepada masyarakat yang belum mengenal tulisan. Akan tetapi bukan berarti hukum belum terbentuk pada ummat-ummat sebelum Nabi Musa ketika tulisan

${ }^{46}$ Lihat Joseph Schacht, Pre-Islamic Background and Early Development of Jurisprudence: in Law in The Middle East, edited by Majid Khadduri and Herbert (Liebesny: Middle East Institute, 1995), 28-30. dalam bukunya ini Joseph Schact ingin membuktikan bahwasanya sunnah yang diklaim berasal dari zaman Nabi Muhammad sebenarnya berasal dari tradisi dari umat Islam abab ke $3 \mathrm{H}$. Menurutnya tidak ada bukti otentik secara tertulis sebelum abad $3 \mathrm{H}$ adanya sunnah Nabi Muhammad.

${ }^{47}$ Huruf dinding ini dipercaya sebagai huruf-huruf simbol yang diciptakan oleh manusia yang dapat menceritakan dengan detail tentang suatu peristiwa. Lihat James. P. Allen, Middle Egyptian, An Introduction to the Language and Culture of Hieroglyph (London: Cambridge University, 2010), h. 15. 
belum ditemukan, ${ }^{48}$ dan itu mustahil. Para ulama akan terus mengalami kesulitan dalam menghasil ijtihad yang original dalam merespon persoalan ummat yang kian terus mengalami perkembangan yang luar biasa bila hanya menggunakan pola-pola konvensional. salah satu hal yang menjadi kelemahan para ulama selama ini dalam menghasilkan hasil ijtihad yang original yang belakangan kurang kritis terhadap metodologi ulama klasik dalam memahami al-Qur'an dan hadis. ${ }^{49}$ Terutama dalam masalah hadis, persoalan utama kemandegan berijtihad hukum di kalangan ulama karena laju perkembangan masyarakat tidak sebanding dengan kemampuan para ulama untuk menghasilkan ijtihad yang memadai dalam menjawab persoalan zaman. Sehingga sering sekali tanpa disadari dikotomi antara masalah agama dan sosial kemasyarakatan terbentuk karena pihak ulama yang secara defacto memiliki otoritas dalam memecahkan persoalan masyarakat diasumsikan tidak memiliki kapasitas dalam memecahkan persoalan yang ada.

Kajian fikih ${ }^{50}$ yang menitikberatkan pada aspek-aspek perilaku mukallaf di masyarakat cenderung bersifat responsif, artinya kajian fikih bersifat reaktif terhadap perilaku-perilaku masyarakat dengan berlandaskan dalil-dalil nash maupun ijtihad dari para ulama. Sementara Ushul fikih objek kajiannya menyangkut nash al-Qur'an dan hadis, yaitu nash digunakan sebagai rekayasa sosial. ${ }^{51}$ Dengan demikian kajian fikih dan ushul sebenarnya saling terkait dan melengkapi akan tetapi kajian fikih lebih bisa menjelajahi wilayah yang lebih bebas karena berbasis dengan dinamika masyarakat. Masalahnya kajian fikih yang seharusnya dapat menjangkau segala aspek kehidupan manusia terhalang dengan ketentuan-ketentuan klasik yang lebih mengedepankan hierarki kitab-kitab hadis pada posisi puncak yang cenderung mengistimewakan aspek-aspek ibadah ritual. Sehingga dapat dibuktikan sekian lama umat Islam terbelenggu oleh aturan-aturan yang bersifat ad-hoc seperti hierarki Kutub al-Sittah dianggap sebagai yang sesuatu yang tidak boleh diganggu gugat kalau tidak ingin mengatakan kultus.

Adanya kecenderungan untuk memahami hadis bukan hanya dari segi teks cukup mendapatkan reaksi yang beragam dari beberapa kalangan. Sebab pemahaman konteks

${ }^{48}$ Walaupun umat-umat sebelum Nabi Musa tidak diturunkan kitab dalam bentuk tulisan akan tetapi mereka memakai shuhhûf yang secara semantik awalnya bermakna kebiasaan/hukum dalam bentuk tradisi lama kelamaan diartikan lembaran-lembaran tulisan setelah dikonversi ke dalam bentuk huruf-huruf.

${ }^{49}$ Lihat Fazlur Rahman, "Historical Versus Literary Critism", in Approaches to Islam in Religious Studies (London: Cambridge University, 2010), h. 233-234.

${ }^{50}$ Kata fikih secara etimologis berarti paham yang mendalam. Bila "paham" dapat digunakan untuk hal-hal yang bersifat lahiriah, maka fikih berarti paham yang menyampaikan ilmu lahir kepada ilmu batin. Karena itulah Tarmidzi menyebutkan, "fikih" tentang sesuatu," berarti mengetahui bathinnya sampai kepada kedalamannya, lihat Amir Syarifuddin, Ushul Fiqh (Jakarta: Prenada Media Group, 2009), 2. Atau lihat definisi fikih secara definitif ialah "llmu tentang hukumhukum Syarî̀ yang bersifat amaliah yang digali dan ditemukan dalam dalil-dalil yang tafsili".

${ }^{51}$ Khoiruddin Nasution, Isu-Isu Kontemporer Hukum Islam (Yogyakarta: Suka Press, 2007), h. 34 . 
lebih dekat dengan pemahaman hermeneutika terhadap teks hadis itu sendiri pastinya akan menimbulkan dampak yang cukup signifikan terhadap hadis itu sendiri. Kalau kajian konteks itu sendiri sudah lama dibahas di kalangan fukaha itu sendiri, sementara itu tidak sedikit ulama yang berusaha memahami isi dari teks-teks nash hadis terhadap pesan moral disampaikan. Munculnya pemahaman nash dari segi maqâsid syarîâh secara tidak langsung menggambarkan pesan nash secara tekstual terkadang kurang bisa memenuhi kebutuhan masyarakat terhadap hukum. Sangat disayangkan selama ini kajian konteks juga hanya menitik beratkan dari sisi qiyas yang secara tidak langsung juga tidak beranjak dari kajian teks nash itu sendiri. Sulit beranjak dari kajian qiyas merefleksikan dominasi socio-kultural Arab sebagai budaya, hal tersebut dapat menghambat perjalanan hukum Islam yang berada pada wilayah yang jauh dari kultur Arab. Qiyas merupakan produk hukum yang sudah dianggap sebagai instrumen dalam melakukan ekstraksi nash ternyata sering menjadi faktor yang menghambat pengkembangan hukum Islam itu sendiri. Karena masih sangat terfokus pada wilayah teks nash yang ternyata kurang mengkomodir situasi kekinian.

Salah satu instrumen dalam memajukan daya kritis terhadap heirarki kutub al-sittah dengan melakukan pendekatan secara hermeneutik. Pendekatan ini diasumsikan dapat membongkar batas antara wilayah sakral dan profan yang meletar belakangi kuatnya otoritas yang dihasilkan dari hierarki kutub al-sittah. Akan tetapi, tidak sedikit di kalangan internal umat Islam yang menolak pendekatan ini dikhawatirkan akan menodai kesucian dari hadis itu sendiri. Ada dua pemahaman tentang konsep nash itu sendiri, yaitu sebagai sesuatu yang bersifat siap saji atau bahan baku yang berkualitas sehingga dibutuhkan pemikiran yang mumpuni dalam mengolah bahan tersebut menjadi bahan jadi. Sebaiknya konstalasi kutub al-sittah dianggap sebagai bahan baku bagi generasi setelahnya pasca kodifikasi hadis berakhir akhir abad ke-4 H. Artinya umat Islam generasi selanjutnya masih memiliki otoritas yang kuat dalam melakukan evaluasi terhadap komposisi hierarki kutub al-sittah itu sendiri. Karena komposisinya bukan bersifat permanen hanya adhoc sesuai dengan kondisi masa kodifikasi hadis yang cenderung pada hadis-hadis berorientasi akhirat.

Masalahnya yang timbul dalam kajian hermeneutika menurut kalangan yang menentangnya menempatkan teks-teks nash yang dianggap sakral sama dengan teks-teks buatan manusia. ${ }^{52}$ Penolakan ini didasarkan bahwasanya kajian hermeneutika itu dapat menggannggu keyakinan orang-orang awam, karena di dalam kajian hermeneutika relatifitas penafsiran sangat diagungkan belum lagi unsur ambiguitas yang terdapat di dalamnya. Sebenarnya spirit hermeneutika itu sendiri sudah ada dalam sejarah Islam dengan munculnya aliran teologi Muktazilah yang mengklaim bahwasanya Qur'an itu adalah makhluk bukan kalamullah yang bersifat abadi. Sebenarnya Muktazilah bukan tidak punya misi ilmiah di balik pengusungan Qur'an adalah makhluk pastilah ingin menggali pesan-pesan moral

${ }^{52}$ Williem Stacy Johnson, "The Domisticatio of Transcendence: How Modern Thinking about God went Wrong," dalam Theology Today 54.1 (April 1997), h. 94-96. 
yang terkandung di dalamnya akan terkuak bila memperlakukan Qur'an sebagai teks yang profan. Ketika memperlakukan suatu nash itu didasarkan atas teks profan secara otomatis unsur-unsur budaya yang meliputi teks suci tersebut perlu dikaji secara mendalam, karena bagaimana pun nash itu sendiri menggunakan teks manusia yang memiliki segala keterbatasan untuk membawa pesan moral yang tak terbatas. Apakah pesan dari Allah dapat ditangkap secara sempurna hanya bila menggunakan pemahaman terminologi teks nash itu diturunkan. Sebab Allah sendiri mengklaim wahyunya berlaku untuk sepanjang zaman dengan demikian perlu adanya media yang menghubungkan antara pesan Allah yang bersifat absolut dengan teks nash yang ada serta kondisi zaman manusia yang menerima teks nash tersebut.

Kekhawatiran penafsiran yang bebas tanpa terkendali terhadap teks-teks hadis dapat dilakukan dengan membuat barometer yang jelas wilayah yang tidak boleh dilanggar dalam melihat sisi kontekstual hadis. Sebenarnya selama penafsiran teks hadis tersebut tidak keluar dari koridor Rukun Islam dan Rukun Iman, maka hal tersebut tidak menjadi masalah.

\section{Penutup}

Jadi penelitian ini diharapkan dapat memberikan kontribusi yang baik dalam menganalisis sejarah lahirnya Kutub al-Sittah sehingga menjadi kitab-kitab hadis yang otoritatif dalam menentukan serta menjadi penjelmaan syariah selain al-Qur'an. Hal ini penting untuk memetakan wilayah-wilayah otoratif nash yang absolut dan wilayah yang sebenarnya hanya memiliki otoritas yang relatif. Penelitian ini diharapkan dapat menulusuri apakah Kutub al-Sittah dalam tataran normativitas seperti al-Quran sehingga hierarkinya tidak dapat dikritisi lagi atau hanya sebuah historitas semata sehingga akan didapatkan bahwa hirarki Kutub al-Sittah hanyalah perjalanan sejarah saja yang di dalamnya bukan menyangkut masalah sakralitas suatu nash akan tetapi karena perjalanan sejarah yang mengarahkan terbentuknya suatu paradigma tentang hierarki kitab-kitab hadis.

\section{Pustaka Acuan}

'Âbad al-Jâbirî, Muhammad. Nahnu wa al-Turâts. Kairo: Markaz al- Thaqâfî al-Arabî, 1993.

Abbott, Nabia. Studies in Arabic Literary Papyri. II: Qur'anic Comentary and Tradition in Early Development of Written Tradition. Khicago University Press, 1967.

Abd al-Wahab Khallâf. Sejarah Pembentukan dan Perkembangan Hukum Islam, terj. Wajidi Sayadi. Jakarta: RajaGrafindo Persada, 2002.

Abu Rayyah, Adhwa' ala Sunnah wal Muhammadiyah au Difâ'u 'ala al-Hadis, Kairo: Dâr al- Ma'ârif, 1119 H.

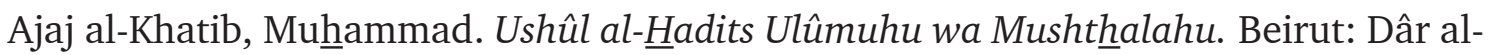
Fikr, 1989. 
Al-'Asqalâni, Ibn Hajar. Hady al-Sârî, 8-14. Abû Bakar Muhammad ibn Mûsâ al-Hâzimî, Shurût A"immat al-Khamsah. Beirut: Dâr al-Kutub al-"Ilmîyah, 1984.

Al-Awânî, Thâhâ J.. Taqlid and the Stagnation of the Muslim Mind. t.t.p.: American Journal of Islamic Social Science Volume. 8, No.3, 1991.

Allen, P. Middle Egyptian: An Introduction to the Language and Culture of Hieroglyph. London: Cambridge University, 2010.

Al-Maqdîsi, Abû al-Fadhl Muhammad ibn Thâhir. Shurût al-A'immat al-Sittah. Beirut: Dâr al-Kutub al-'Ilmiyah, 1984.

al-Minqarî, Nasr ibn Muzahîm. Waq‘at Siffin. Edited by ‘Abd al-Salâm Muhammad Harûn. Beirut: Dâr al-Jîl, 1990.

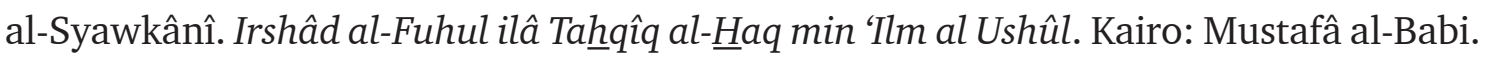
Al-Halabî wa-Awlâduh, 1973.

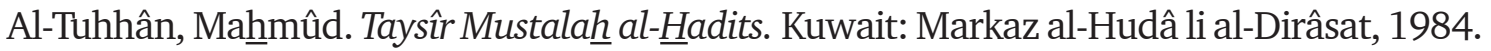

Arkoun, Mohammed. "The Concept of Authority in Islamic Thought: Lâ Hukma Illâ Lillâh," in The Islamic World: From Classical to Modern Time, Edited by C. E. Bosworth, Charles Issawi, Roger Savory and A.L Udvitch. England: The Darwin Press, 2010.

Arkoun, Mohammed. The Concept of Authority in Islamic Thought. England: Oxford University Press, 2010.

Bernstein. Richard. "The Uneasy Tensions of Immanence and Transcendence." dalam International Journal of Politics, Culture and Society 21.1-4, December 2008.

Brockopp Jonathan E. "Rereading the History of Early Maliki Jurisprudence." dalam Journal of the American Society, April-June 1998.

Calder, Norman. Islamic Jurisprudence in Classical Era, edited by Colin Imber. Cambridge University Press, 2010.

Christopher Melchert, Brown, and the Others. The Canonization of al-Bukhari and Muslim: Formation and Function of Sunni (Latin Capital Letter with Dot Below) Hadits Canon. Cambridge: Cambridge University Press, 2008.

Christopher Melchert. "Early Renunciants as Hadits Transmitters." dalam The Muslim World 92.33:4, Fall 2002.

Cobb, Paul M. "Reinterpreting Islamic Historiography: Harun al-Rashid and Narative of the Abbasid Caliph," dalam Journal the American Oriental Society 12.1, JanuaryMarch 2001.

El Shamsy. Ahmed. "Al-Shafi's Written Courpus: A Source - Critical Study." dalam Journal of American Society 132.2, April-June 2012.

Farouq Abu Zaid. Al-Syarî‘at al-Islâmiyyah Bayn al-Muhâfizîn wa al-Mujaddidîn, terj. Husain Muhammad. Jakarta: P3M, 1986.

Hamidullah, Muhammad. "Early History of the Compilation of the Hadits," dalam Islamic Literature, Vol. 12, No. 3, Lahore, 1966. 
MIQOT Vol. XXXVIII No. 1 Januari-Juni 2014

Hamidullah, Muhammad. Aqdam Ta'lifi al-Hadis al-Nabawi-Shaĥifah Hamman ibn

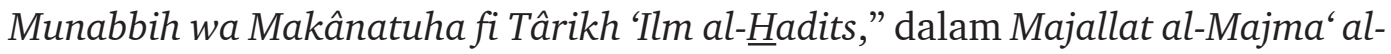
'Ilmi al-Arâbi, 28, 1953.

Hamidullah, Muhammad. The Earliest Extant work on The Hadits: Shahîfah Hamman ibn Munabbih, comprising al-Shahîfah al-Shahîhah of Abû Hurayyah, prepared for Pupil Hamman ibn Munabbih, together with an introduction to the History of the Early Compilation of hadis. Paris: Center Culturel Islamique, 1961.

Johansen, B. Contingency in a Sacred Law. Leiden: Brill, 1999.

Johansen, B. Legal Literature and the Problem of Change, in Islam and Public Law, ed. C. Mallat. London: Graham and Trotman, 1993.

Jokisch. Benjamin. Islamic Imperial Law: Harun al-RaShid's Codification Project. Berlin: Walter De Gruyter, 2007.

M. Glen Coper. “The Qur'an's Self-Image: Writing and Authority in Islamic's Scripture.” dalam Journal of the American Oriental Society 123.1. January-March 2003,

M.M.Azami. Studies in Early Hadits Literature: With a Critical Edition of Some Early Texts. Indianapolis: American Trust Publication, 1968.

Madelung, Wilferd, Sabine Schmidtke. Rational Theology in Interfaith Communication: Abu al-Husayn al-Basri's Mu'tazili Theology among the Karaites in Fatima Age. Leiden: Brill, 2006.

Mernissi, Fatima. The Veil and the Male Elite: A Feminist Interpretation of Women's Rights in Islam, transl. Mary Jolakeland. New York: Basic, 1991.

Musnad Ahmad bin Hambal, Juz V, t.t.p. : t.p., t.t.

Rahman, Fazlur. Historical Versus Literary Critism, in Approach to Islam in Religion Studies. England: Cambridge University, 2010.

Rahman, Fazlur. Islam and Modernity. Chicago: University of Chicago Press, 1982.

Schacht, Joseph. "Pre-Islamic Background and Early Development of Jurisprudence," in Majid Khadduri and Herbert (ed.) Law In The Middle East. Liebesny: Middle East Institute, 1995.

Schacht, Joseph. The Origins of Muhammadan Jurisprudence. Oxford: Clarendon Press, 1959.

Sezgin, Fuat. "Islam History of Science and Technology Needs to Speak," dalam Turkish Daily News, 27 December 2008.

Shaikh Muhammad al-Khudharî. Tarîkhal-Tashri‘ al-Islam. Beirut: Dâr al-Kutub al-Islamiyah, t.t.

Syarifuddin, Amir. Ushul Fikih. Jakarta: Prenada Media Group, 2009.

Wael B. Hallaq. An Introduction to Islamic Law. Cambridge University Press, 2009.

Wael B. Hallaq. 'Was the Gate of Ijtihâd Closed?', dalam International Journal of Middle East Studies, 16, 1984. 